\title{
Principal Performance Evaluation Model in Managerial Field in Improving Kindergarten Teacher's Professionalism
}

\author{
Lia Yuliana \\ Faculty of Education \\ Universitas Negeri Yogyakarta \\ Yogyakarta, Indonesia \\ lia_yuliana@uny.ac.id
}

\begin{abstract}
The purpose of this research was to determine the evaluation model of kindergarten principal performance of managerial field in DIY. This study used Research and Development method, which consists of four stages, namely: (1) the preliminary stage, (2) the evaluation model planning stage, (3) the pilot stage, evaluation and revision, and (4) the implementation stage. The results showed that the guide devices on the implementation of principal performance evaluation in managerial field were declared eligible by the experts. The instruments readability in assessing the performance of 12 principals in managerial field was 1.87 and categorized as excellent. While the assessed performance level in managerial component of 20 kindergarten teachers' was 1.90 and categorized as excellent. The total average of principal performance level as an effort to improve the professionalism of kindergarten teachers in 19 schools was 1.90 with 1.75 for the managerial component and categorized as excellent. While the assessed performance level for the managerial component by 30 kindergarten teachers showed 1.92 or categorized as very well.
\end{abstract}

Keywords-evaluation, performance, principal, and teacher professionalism.

\section{INTRODUCTION}

In an educational system, the quality of learning is influenced by the availability facilities and infrastructure of learning, activity and creativity of teachers and students' learning process. Teaching and learning activities would be qualified if supported by professional teachers who had professional competence, pedagogical, personality, and social (Law on Teachers and Lecturers Article 10). In addition, the quality of learning could also be maximized if it was supported by qualified students (intelligent, have a high motivation to learn and a positive attitude in learning), and supported by adequate learning infrastructure.

The school principal as instructional leader was one of the determining factors that could encourage schools to realize the vision, mission, goals and objectives through various programs carried out in a planned manner. Can as quoted by [1] stated that principal is the most factor to help students to be beneficial for society and environment.

In addition, Ubben and Hughes, as quoted by [2], proposed that school principals should create good school climate to make the productivity of teachers and the students can be improved. They also added that, principal should have leadership style to foster the school effectiveness. It is also supported by [3] statement who stated that the success of the school improvement effort depends on the effort of professionalism development of the school which is teachers' professionalism development. [4] added that school principal concerns to practices and operations of educational management including economics, general management, political science, psychology, and sociology.

Therefore, principals were required to work professionally and responsive to the aspirations of the people and the dynamics of environmental change. Principals should also be able to accomplish tasks effectively and efficiently. The ability of a principal in leading a school would be very influential in improving the professionalism of the teachers.

This research focused on the performance evaluation model of kindergarten principals in managerial field in improving the professionalism of kindergarten teachers in Daerah Istimewa Yogyakarta. Based on the problem identification above, the problem formulation was how the level of managerial field principal performance in improving the professionalism of kindergarten teachers in Daerah Istimewa Yogyakarta.

\section{A. Theoretical Framework}

School principal as the educational leader should be able to improve the education quality and reach the goals of institution. Therefore, the school principal should have good leadership in improving the education components. As quoted by [5], Gul, Rehman, Rassaq, Ahmad and Saif described leadership has motivation in the process of fulfilling someone self-interest, achieving the institution's goals, and pursuing new directions for success. To create a new vision for the organization, the transformational leader should have these roles, so that the principal in the schooling system has better performance in scholastic and make all teaching staffs have the same vision to achieve the school's goals. School leaders have relation representative for both the area of attendance and between teachers and the district office. [6] They as principal could be a director and evaluator of teaching effort, a manager of school facility, and a professional leader.

In addition, to have effectiveness in schooling system, [7] found conceptual skills as transformative leadership skills 
of principals where they are able to identify and sustain the school vision. It was discovered to enhance school effectiveness by improving the teachers' commitment and motivating them to achieve the school goals.

School principals who need to transform the schooling system must possess relevant managerial skills where managerial skills are essential capabilities that determine the extent of the educational goals and According to Okoye, Fullan, and Mestry, as cited by [8], managerial skill is the ability to plan, control, organize, staff, coordinate and control directly the operations of an educational enterprise in order to achieve the whole objective target for educational system and to have effective management of schools.

In addition, as stated by Katz in [9] and [10] a leader should have three basic skills, which are conceptual skills, human relation skills, and technical skills. Conceptual skills are needed by school principals where they must perceive the significant elements in a situation, make decisions relevant to conceptual patterns, resource allocation and require a broad perspective. On the other hand, human skills are also important for school principals to help them in managing individuals from a wide variety of departments or areas of subject matter, other technical experts (such as counselors, social workers, school psychologists, and department heads), and to have interact productively with upper-level administrators. Regarding to the evaluation of principal, it requires standards to guide professional practice, hold the professionals accountable, and provide goals for upgrading the profession's services. In addition, [11] proposed the performance of the principal had to be examined in five general areas: (a) academic learning and social development of the students, (b) learning environment of the school, (c) development and involvement of faculty and staff (d) involvement and satisfaction of parent and community, and (e) management of financial and program.

On the other hand, principal as a key player in providing development of professional to teachers in interpreting growth and accountability measures. [12] One of the framework of instructional leadership or principal is where principal could provide opportunity in professional development for teachers. [13] Regarding to improve the professionalism of teacher, [14] defined the moral foundations of teacher professionalism. According to him, professionalism is a manner of conduct within an occupation, how members integrate their knowledge and skill with obligations in the context of collegiality, and ethical relations with clients. He also identified five aspects of professionalism for teachers, namely character, commitment to change and continuous improvement, knowledge in subject and pedagogical, obligations and working relationships beyond the classroom.

\section{SEARCH METHOD}

This study used a Research and Development method which consisted of four stages, namely: (1) the preliminary stage, (2) the evaluation model planning stage, (3) the pilot stage, evaluation and revision, and (4) the implementation stage. The trial subject in this study was conducted three stages: pre-trials involving 3 experts and practitioners in education; testing the readability of instruments and guidelines which were applicable to 9 trial subjects to kindergarten principals in Daerah Istimewa Yogyakarta; and field operations trial which were applied to 19 trial subjects to kindergarten principals in some kindergartens in the Yogyakarta city, Bantul and Kulon Progo in Daerah Istimewa Yogyakarta. The technique collecting data used questionnaires, documents, observation, and interviews. Validity and reliability of the questionnaires instrument used the expert validation. While the validity of qualitative data was validated by the review informant model and triangulation of data. Quantitative data analysis was descriptive analysis techniques and qualitative data was interactive analysis model.

\section{A. Research Result}

\section{RESULTS AND DISCUSSION}

The performance evaluation guide of the principal in managerial field named EKKSBM developed in this study was a model used to evaluate the performance of school principals in managerial field of Kindergarten in order to improve the professionalism of teachers. The activity of Research and Development (R \& D) through the pre-survey, theoretical studies including relevant research review, requirements analysis, test empirically, and practice in the field had finally found a concept model of kindergarten principal performance evaluation in managerial field in order to improve the professionalism of teachers. Principal performance evaluation in managerial field concept generated through the process of discussion of the research team, discussions with experts, seminars instrument, and the appropriateness test in the field. Before the instrument was tested, all items had been validated by experts and practitioners of educational management. Theoretical studies, empirical, and practice in the field as well as intensive discussions with the research team and the various parties through field trials showed that the instrument EKKSBM was good to be used to assess the performance of kindergarten school principals in managerial field.

Researcher simplified into four stages in accordance with the procedure of Research and Development. Four stages, namely: (1) the preliminary stage where the stage of research and information gathering related to the performance of kindergarten principals in managerial field and professionalism of teachers in Daerah Istimewa Yogyakarta, (2) the planning stage of principals' performance in managerial field assessment instrument and principal performance evaluation guidance as the development of early product form, (3) the validation stage, and (4) the implementation stage or field operational tests where it is to find the performance level of kindergarten teachers and principal in DIY. The validators in this study are three experts: evaluation expert, education management expert, early childhood expert. Nine school principals, 12 school principals in the main trial also validated, as well as in the field operations test consisted of 19 kindergarten principals from the city of Yogyakarta, Bantul and Kulon Progo. Techniques of collecting data used questionnaires, documents, and observation. The instrument validation used expert validation or expert judgment. 
1) Performance Level of Kindergarten Principal in Managerial Field in DIY For Main Test

The results of the major trial against 9 kindergarten school principals and 20 teachers of kindergarten teachers obtained performance level of school principals in managerial field as follows.

Table 1

Assessment Result of School Principal and Teachers againts Performance of School Principal in Managerial Field

\begin{tabular}{|c|c|c|c|}
\hline \multirow{2}{*}{$\begin{array}{c}\text { Performance } \\
\text { Component } \\
\text { of School } \\
\text { Principal } \\
\end{array}$} & \multicolumn{2}{|c|}{ Assessment } & \multirow[b]{2}{*}{$\begin{array}{c}\text { Variable } \\
\text { Score } \\
\text { Mean }\end{array}$} \\
\hline & Teacher & Principal & \\
\hline $\begin{array}{l}\text { Managerial } \\
\text { field }\end{array}$ & 1.90 & 1.87 & 1.885 \\
\hline
\end{tabular}

If the values were converted into a numerical value 1100 , it would obtain values of good performance based on the evaluation of teachers and principals as follows.

Table 2

Assessment Result of School Principal and Teacher against Performance of School Principal in Managerial Field

\begin{tabular}{|c|c|c|c|}
\hline \multirow{2}{*}{$\begin{array}{c}\text { Performance } \\
\text { Component } \\
\text { of School } \\
\text { Principal }\end{array}$} & \multicolumn{2}{|c|}{ Evaluator } & \multirow[b]{2}{*}{$\begin{array}{c}\text { Variable } \\
\text { Score } \\
\text { Mean }\end{array}$} \\
\hline & Teacher & Principal & \\
\hline $\begin{array}{l}\text { Managerial } \\
\text { field }\end{array}$ & 95 & 93.5 & 94.3 \\
\hline
\end{tabular}

The result of school principals and kindergarten teachers about the performance level of kindergarten principal in managerial field in DIY categorized as excellent.

2) Trial Implementation or Field Operational

The performance level of kindergarten school principal in DIY based on assessment of 19 principals and 30 teachers of kindergarten used in trial implementation could be shown as follows.

Table 3

Teacher Assessment Results against Performance of Scool Principal in Managerial Field

\begin{tabular}{|c|c|c|c|}
\hline $\begin{array}{c}\text { School Principle } \\
\text { Performance } \\
\text { Component }\end{array}$ & \multicolumn{2}{|c|}{ Evaluator } & Variable \\
\cline { 2 - 3 } & Teacher & Principal & $\begin{array}{c}\text { Score } \\
\text { Mean }\end{array}$ \\
\hline Managerial field & 1.92 & 1.75 & 1.835 \\
\hline
\end{tabular}

If the values were converted into a numerical value 1100 , it would obtain values of good performance based on the evaluation of teachers and school principals as follows. Table 4

Teacher Assessment Results against Performance of School Principal in Managerial Field

\begin{tabular}{|c|c|c|c|}
\hline $\begin{array}{c}\text { School Principal } \\
\text { Performance } \\
\text { Component }\end{array}$ & \multicolumn{2}{|c|}{ Evaluator } & Variable \\
\cline { 2 - 3 } & Teacher & Principal & $\begin{array}{c}\text { Score } \\
\text { Mean }\end{array}$ \\
\hline Managerial field & 96.0 & 87.5 & 91.75 \\
\hline
\end{tabular}

Based on the evaluation result, the managerial field of the principal performance evaluation could be categorized as very high.

\section{DISCUSSION / ANALYSIS}

Based on the main test stage implemented in 12 kindergarten school principals and 20 kindergarten tearchers in DIY, it could be concluded that the excellent performance of the school principal in managerial field namely with a mean score rating of 1.90 categorized as excellent. It was not just based on self-assessment of school principals, but also based on the assessment of teachers toward the principal. The findings in the study were also supported by observations result and interviews with teachers and school principals that indicated the kindergarten principal's performance was very good. Performance should be maintained and even improved so that it could support the professionalism of teachers in serving students. Likewise, by the field operational test stage applied to the 19 kindergartens school principals and 30 kindergarten teachers in DIY, it could be concluded that the excellent performance of the school principal in managerial field that was 1.88 for assessment mean score can be categorized as very good. It was not just based on selfassessment of school principals, but also based on the assessment of teachers towards the school principal, although teacher's assessment was more optimal than the school's principal assessment itself. This showed that the assessment was done with a high degree of objectivity and the data were not biased.

The findings in the study were also supported by observations and interviews with teachers and school principals who indicated that kindergarten school principal performance in managerial field was very good. Based on the results of the school principal performance evaluation in managerial field of the implementation stage, it could be arranged in the following evaluation result report form.

Table 5

Performance Evaluation Report of School Principal

\begin{tabular}{|c|c|c|c|c|c|c|}
\hline \multirow[b]{2}{*}{$\begin{array}{c}\text { Assessment } \\
\text { Aspects }\end{array}$} & \multirow{2}{*}{$\begin{array}{l}\text { Score } \\
\text { Mean }\end{array}$} & \multicolumn{5}{|c|}{ Classification } \\
\hline & & $\mathbf{L}$ & $\mathbf{E}$ & $\mathbf{G}$ & VG & $\mathbf{E}$ \\
\hline Managerial field & 91.75 & & & & & $\sqrt{ }$ \\
\hline
\end{tabular}

Another study that has been implemented by Williams (2009) showed that the model of assessing the principal performance have served the preparation of school administrator programs extremely well and principals become expert in their leadership skills during internships. They learn to manage their professional conducts in facilitating and enhancing their leadership. In assigning all of the activities within the school, Muraina (2014) added that the principals should handle the responsibility of it, try to keep a high level of professional and good moral standard of the schools, and learn to adopt their management styles to have good working environment for teachers and other staff in their schools.

\section{CONCLUSION}

Based on the results of research and discussion, it could be concluded that the level of performance of the school principal in managerial field as an effort to improve the professionalism of kindergarten teachers in 19 schools showed a mean score of 1.75 could be categorized as excellent. While the level of performance that was assessed by 30 kindergarten teachers was at 1.92 for the managerial field or could be categorized as excellent. 


\section{REFERENCES}

[1] Memisoglu, Assoc. Prof. Dr. Salih Pasa. (2015). The perception of teachers about management skills of school principals. International Journal of Humanities and Social Science, Vol 5 No 2 (pp. 21-29)

[2] Ibrahim, Ali S. and Al-Taneiji, Shaikah. (2013). Principal leadership style, school performance, and principal effectiveness in Dubai schools. International Journal of Research Studies in Education, Volume 2 Number 1 (pp. 41-54)

[3] DuFour, R \& Barkey, T. (2005). The principal as staff developer. Journal of Development, Fall 2005, Volume 16. Number 4.

[4] Farah, Abdikadir Issa. (2013). School management: characteristics of effective principal. International Journal of Advancements in Research \& Technology. Volume 2, Issue 10. (pp. 168-173)

[5] Selesho, JM, and Ntisa, AA. (2014). Impact of school principal leadership style on performance management: a schooling agenda. Mediterranean Journal of Social Sciences, Vol 5 No 3 (pp. 211-218)

[6] Williams, Henry. (2009). An evaluation of principal interns performance on the interstate school leaders licensure consortium standards. National Forum of Educational Administration and Supervision Journal. Volume 26, Number 4.

[7] Bolanle, Akinola Oluwatoyin. (2013). Principals' leadership skills and school effectiveness: the case of south western Nigeria. World Journal of Education. Vol. 3, No. 5 (pp. 26-33)

[8] Egboka, Patience Ndidi (PhD)1, Ezeugbor, Carol Obiageli (PhD)2 \& Enueme, Chika Peace (PhD)3. (2013). Managerial skills and enhancement strategies of secondary school principals. Journal of Education and Practice. Vol.4, No.26. (pp. 168-174)

[9] Werang, Basilius Redan. (2014). Principals' manajerial skills, schoo organizational climate, and teachers' work morale at state senior high schools in merauke regency-papua-indonesia. International Journal of Science and Research (IJSR). Volume 3 Issue 6. (pp. 691-695)

[10] Lunenburg, Fred C. (2010). The principal and the school: what do principals do?. National Forum of Educational Administration and Supervision Journal. Volume 27, Number 4. (pp. 1-13)

[11] Stufflebeam, Daniel \& Nevo, David. (1993). Principal evaluation: new directions for improvement. Peabody Journal of Education. Vol. 68, No. 2. (pp. 24-46)

[12] Harper, Brenda L. (2015). Considering principal evaluation as means of renewal, reflection and growth. Advancing Women in Leadership, Full Length Research Paper. Vol. 35, pp. 76- 81

[13] Prytula, Michelle., Noona, Brian., Hellsten, Laurie. (2013). Toward instructional leadership: principals' perceptions of large-scale assessment in schools. Canadian Journal of Educational Administration and Policy, Issue 140

[14] Tichenor, Mercedes S \& Tichenor, John M. (2004). Understanding teachers' perspectives on professionalism. The Professional Educator. Volume XXVII, Number 1 \& 2. (pp. 89-95)

[15] Muraina, Monsuru Babatunde. (2014). Principals' managerial skills and administrative effectiveness in secondary schools. Global Journal of Management and Business Research: A Administration and Management. Volume 14 Issue 3. 